\title{
Insolvency within Bankruptcy: The Case in Indonesia
}

\author{
$M$ Fauzi ${ }^{1, *}$ \\ ${ }^{1}$ Faculty of Law, Universitas Mulawarman, Samarinda, Indonesia
}

\begin{abstract}
The Bankruptcy institutions are an extraordinary mechanism in debt settlement. The extraordinary characteristic distinguishes bankruptcy institutions with other mechanisms in debt settlement. This particular characteristic stems from the debtor's inability to pay all of his debts due. However, two of the Indonesian bankruptcy laws do not include insolvency conditions as the basis for granting bankruptcy status to the debtor. Such legal politics resulted in the use of bankruptcy institutions deviated from their philosophy and vulnerable to abuse. With a post-positivist approach, this paper examines the position of insolvency tests on bankruptcy institutions, why insolvency tests are not carried out in Indonesian bankruptcy law, and how to place insolvency tests in Indonesian bankruptcy law. This study concludes that test insolvency is an essential element of bankruptcy institutions. Without insolvency tests, the bankruptcy institutions lose its raison d'etre. Proving that the debtor in insolvent condition cannot be done easily, so that Insolvency test is not used as a condition in granting bankruptcy status for debtors in Indonesia. Insolvency tests should serve as the basis for granting bankruptcy status to debtors by setting aside the principle of simple evidentiary systems. Thus, only by applying insolvency tests of bankruptcy institutions work properly.
\end{abstract}

\section{Introduction}

Bankruptcy is still become a nightmare in Indonesia. The lack of petition for bankruptcy and controversy within the community regarding bankruptcy proves this assumption. Bankruptcy institutions still cannot work properly due to several factors, including in terms of legal norms, law enforcement infrastructure and the culture of the community itself. Law No. 37 of 2004 on Bankruptcy and Suspension of Debt Payment Obligation (Bankruptcy Law), as well as the previous bankruptcy legal regime, has so far been compiled by ad-hoc as a response to the economic crisis or a case that seizes public attention so that it cannot anticipate various problems in a bankruptcy process. The situation is exacerbated by the lack of commercial judges who have sufficient competence in the area of bankruptcy. The resulting decisions which are contradictory undermine the legitimacy of the Pengadilan Niaga (commercial court). The number of legal loopholes is vulnerable to being misused. With all these problems the bankruptcy institution is increasingly unattractive to the community, an institution that is not rooted in the values and culture of Indonesian society.

\footnotetext{
*Corresponding author: fauzi.sh@gmail.com
} 
The drafting and amending process of the bankruptcy law which is only carried out in response to major cases and the economic crisis formed the legal politics of the Bankruptcy Law which emphasized on the protection of the creditors' interests. It can be inferred to the mechanisms and processes of bankruptcy which provide broad rights and powers to the creditors, among them are manifested in simple bankruptcy filing requirements (Article 2 point (1) Bankruptcy Law), simple evidentiary systems (Article 8 point (4) Bankruptcy Law), as well as debt in a broad sense (Article 1point (6) Bankruptcy Law) which result in the large number of parties can be a creditor in bankruptcy (Explanation of Article 2 point (1) Bankruptcy Law). Creditors retain the right to claim to the debtor even though the bankruptcy process has been completed as long as the loan has not been fully repaid (Article 204 Bankruptcy Law). The absence of debt forgiveness principles is a consequence of the absence of insolvency tests in Indonesian bankruptcy law. Whereas, without the insolvency test, the bankruptcy institution changes only as a forced tool to collect debts, far from its main function as a mechanism to settle debt debts that are specific in nature.

This paper uses a post-positivist approach to examine the relevance of solvency tests in bankruptcy institutions, why insolvency tests do not carried out in Indonesian bankruptcy law, and how to occupy insolvency tests in Indonesian bankruptcy law. Bankruptcy law here is seen as a set of rules which the validity will be influenced by other factors in society (law as it is in society).

\section{Bankruptcy as an unnatural procedure}

The specific nature of the Bankruptcy institution is attached to its function as a particular debt settlement procedure [1-4]. This particular character is based on the state of the debtor who is in an unfortunate situation as the entirety of his assets is not enough to pay for all his debts (insolvent). In this situation, each creditor certainly has an interest in getting paid off for his receivables. The settlement of claims from a creditor in this situation is certainly detrimental to other creditors (common pool problems) [3]. A collective mechanism is needed in this circumstance to protect the interests of all creditors. For the sake of the effectiveness of the collective mechanism, the nature of the lex specialist is given to the bankruptcy law when dealing with other legal regimes that are enforced in normal situations, be it contract law, security law, company law and so on [3]. According to Thomas H. Jackson and Robert E. Scott, all the unnatural attributes of bankruptcy institutions are a consequence of a collective process [5]. All collective procedures require an adjustment of the rights and interests of the parties involved for a collective purpose. Without these adjustments, the bankruptcy institution's function as a collective process will not work as expected.

Bankruptcy institutions as collective mechanisms essentially imply two things, the protection of creditors' interests through the principle of pari passu prorata parte and on the other hand relieves the burden on debtors through discharge. Payment of creditors' receivables can only be taken from what is owned by the debtor as long as the bankrupt status. This means that the process is the last process that resolves the association between debt debtors and their existing creditors. After the debtor's assets are completely depleted, the debtor must be released from the remaining debts he cannot pay. If the process is not a process that resolves the relationship between the debtor and its creditors, then there is no relevance to impose the proportional sharing to the creditors. Each creditor certainly craves his debt to be paid in full as promised rather than proportional payment through a collective mechanism that is obviously detrimental to him. Then it can be concluded that insufficient assets of debtors to pay for all their debts (insolvent) are raison d'etre of bankruptcy institutions [6].The imposition of bankruptcy status on a debtor and the use of bankruptcy institutions to settle its obligations can only be justified if the debtor is in an insolvent state. If the debtor is not insolvent, it cannot be justified to force the collective distribution on the creditors. 
However, the process of ensuring that the debtor is in the insolvent state based on the balance sheet test is not easy and takes a long time. Assessment of assets when a debtor's financial problems occur is not as easy as when the debtor's financial condition is normal. Assessment of assets of debtors is not an exact science. The asset value of the debtor depends on the market situation and the subjectivity of the buyer. This will be more complicated if it is faced with the problem of the amount and total value of debtor liabilities which are also uncertain [7]. These problems are certainly not in line with some of the bankruptcy system which intends to speed up the process in order to maximize the asset value of the debtor. Another impact is that debtors will less earnest in seeking income and or hiding their income [8].Although it is not easy, the insolvent state of the debtor is a prerequisite so without it there is no bankruptcy institution. This solvency test distinguishes the bankruptcy institution from the debt collection mechanism in general.

\section{Looking for solvency test in Indonesian bankruptcy law}

The term insolventie can be found in Article 168 paragraph (1) FaillissementsVerordening 1905 which is also followed by Article 57 paragraph (1) and Article 178 paragraph (1) Bankruptcy Law. The explanation of Article 57 paragraph (1) of Bankruptcy Law expressly refers to the concept of insolvent as stated in Article 178 although in its explanation describe that insolvency is a condition of being unable to pay. Article 178 paragraph (1) Bankruptcy Law state that by law, bankrupt assets in insolvency status if the composition plan is not offered in the creditor's meeting, the composition plan offered is not accepted or the ratification of the composition plan is rejected based on a decision that has obtained permanent legal force. This is implied a legal insolvency, that bankrupt assets must be liquidated as a consequence of not having an agreement on the composition plan or not being approved by the judge. Thus, the status of the debtor is subjectively in the hands of creditors and judges.

Indonesian bankruptcy law does not require debtors in the insolvent state based on balance sheet tests. Instead, in the three Bankruptcy legal regimes that have been applied in Indonesia, each uses the term unable to pay debts and stops paying debts, does not pay at least one debt, and does not pay off at least one debt as a criterion of debtors submitted for bankruptcy. Article 1 paragraph (1) Faillissements-Verordening states that every debtor who is unable to pay his debts in a state of stopping repaying the debt, either at his own request or at the request of a creditor or some creditor, can be stated by the judge that the debtor is in bankruptcy. The concept of not being able to pay or the state of being stopped paying is not defined so that in the judicial practice during the Dutch colonial period the examination of the inability of the debtor was based on the bookkeeping analysis. While post-independence Indonesia only around 8 (out of 167) cases were processed by bookkeeping inquiry [9].

Article 1 paragraph 1 of Government Regulation in Lieu of Law Number 1 of 1998 on Amendment to the Law concerning Bankruptcy into Law (passed as Law No. 4 of 1998) stipulates that a Debtor who has two or more creditors and does not pay at least one debt due and payable is declared bankrupt by an authorized court decision, both on his own application and on request one or more of its creditors. The state of being unable to pay as a criterion is eliminated, even if the unpaid debt just one debt the debtor can be declared bankrupt. According to Sunarmi, changes in the terms from being unable to pay and stopping paying to not paying is a legal politics of bankruptcy law during the monetary crisis to facilitate creditors, especially foreign creditors, to bankrupt their debtors in Indonesia [10].Article 2 paragraph (1) of Bankruptcy Law provides that a debtor who has two or more creditors and does not pay in full at least one debt that due and payable, declared bankrupt by court decision, either on his own application or at the request of one or more of his creditors. The 
criteria for at least one debt that does not pay in full are intended to adjust to the practice of the loan agreement with instalment payments (credit) in the community.

Based on the discussion above, it can be concluded that debtors in insolvent conditions based on balance sheet tests is not adopted in Indonesian bankruptcy law. This is due to the legal politics of the Bankruptcy Law in favour of the creditors' interests. If the concept of insolvent as Article 1 paragraph (1) Faillissements-Verordening is maintained, it will be difficult for creditors (especially foreign investors) to bankrupt their debtors in Indonesia. In addition, the efforts to prove insolvent state of debtors require a complex verification process and a long period of time is considered not in accordance with the Indonesian bankruptcy system which adheres to speed up the process.

\section{Putting the solvency test in Indonesian bankruptcy law}

The special nature of the Bankruptcy institution is attached to its function as a special debt settlement procedure for insolvent debtors. Its use can only be justified if the debtor is in an insolvent state. This distinction is based on differences in consequences between the bankruptcy process and the resolution of default cases in general. Without the insolvent state, the function of bankruptcy institutions is limited to being a tool to suppress and threaten debtors who do not carry out their obligations. All payment claims will be more proposed through a bankruptcy mechanism because it is more effective with a faster and simpler process than the process in the general court. This can disrupt the jurisdiction of each type of court. In the other hand, the bankruptcy institution has deviated from its philosophy and is vulnerable to abuse. Based on this reason, solvency tests need to be reintegrated into Indonesian bankruptcy law.

Solvency test can be applied in Indonesian bankruptcy law with several adjustments. The fundamental adjustment that must be done is a change in perspective on bankruptcy law. Bankruptcy law must be seen as an important part of the legal system as a whole. The development of bankruptcy law must be carried out in a comprehensive and systematic manner, not only as a form of reaction to the crisis situation and or the existence of major cases that cause controversy in the community. The importance of bankruptcy law as part of the legal system can be seen in the practice of developed countries that continually adjust their bankruptcy laws to the development of society.

The concept of simple evidentiary systems is an anomaly of a fact-finding mechanism to resolve a case in court. Limiting the mechanism of evidentiary is the same as reducing the quality of facts and the value of truth to be achieved and its function in solving a case. The policy to accelerate the process of evidentiary should be carried out on material aspects (system of evidence) and not in the evidentiary process. A simple evidentiary system is no longer relevant considering that the economic system has become increasingly complex. The determination of rights and obligations, as well as the legal relationship of the parties in a transaction, is currently quite intricate. Most bankruptcy cases, where the debtor is truly insolvent, will not be able to be resolved at the Pengadilan Niaga (commercial court) if a simple evidentiary system is continued to be enforced. In the other hand, Improvement of a simple evidentiary system can actually lead to injustice due to the judge's mistake caused by a perfunctory verification process.

The Indonesian bankruptcy law states that the procedural law that applies to the bankruptcy process is a civil procedural law. This is appropriate given that the bankruptcy institution is essentially a private institution because it is related to the settlement of rights and obligations between creditors and debtors. The passive position of judge in civil procedure law and limited access of creditors to know the financial condition of the debtor make the process of evidentiary more difficult. To overcome this problem, the judge can 
adjust the burden of proof. In both voluntary and involuntary petition, the burden of proof is placed on the debtor to prove that he is not in an insolvent condition.

\section{Conclusion}

Based on this discussion, it can be concluded that the insolvency state of the debtor is an essential element of the bankruptcy institution. Without solvency test, the bankruptcy institution loses its raison d'etre. Solvency tests are constrained by the simple evidentiary systems and it is not in line with the legal policy that is intended to be implemented. Solvency test should be used as the basis for giving bankruptcy status to debtors by excluding simple evidentiary principles. Thus, by applying solvency test the bankruptcy institution will be functioned properly.

\section{References}

1. J. S. Ziegal, Current Developments in International and Comparative Corporate Insolvency Law (Clarendon Press, Oxford, 1994)

2. B. Wessels, Polak-Wessles, Insolventierecht, Deel 1, Faillitverklaring (Kluwer, Deventer, 1999)

3. T. H. Jackson, The Logic and Limits of Bankruptcy Law (Harvard University Press, London, 1986)

4. D. G. Baird, T. H. Jackson, Corporate Reorganizations and the Treatment of Diverse Ownership Interests: A Comment on Adequate Protection of Secured Creditors in Bankruptcy,U. Chi. L. Rev., 51, 97 (1984)

5. T. H. Jackson, R. E. Scott, On the Nature of Bankruptcy: An Essay on Bankruptcy Sharing and the Creditors' Bargain, Va. L. Rev.,75, 155(1989)

6. R. Tomasic, K. Whitford, Australian Insolvency and Bankruptcy Law(Butterworth, Sydney, 1997)

7. R. M. Goode, The Principles of Corporate Insolvency Law (London: Sweet \& Maxwell, 2011)

8. W. H. Meckling, Financial Markets, Default, and Bankruptcy: The Role of the State, LCP, 41, 4(1977)

9. Sunarmi, Prinsip Keseimbangan dalam Hukum Kepailitan di Indonesia (Softmedia, Jakarta, 2010)

10. Sunarmi, Hukum Kepailitan (Softmedia, Jakarta, 2010) 